\title{
Perencanaan Sistem Manajemen Lingkungan pada Aspek Air Bersih, Limbah, Energi, dan Penghijauan di Pondok Pesantren (Studi Kasus: Pondok Pesantren An-Najiyah Surabaya)
}

\author{
Shinfi Wazna Auvaria', Widya Nilandita' ${ }^{1}$, Sulistiya Nengse ${ }^{1}$ \\ ${ }^{1}$ UIN Sunan Ampel, Surabaya, Indonesia \\ shinfiwazna@uinsby.ac.id \\ ${ }^{2}$ UIN Sunan Ampel, Surabaya, Indonesia \\ widya.nilandita@uinsby.ac.id \\ ${ }^{3}$ UIN Sunan Ampel, Surabaya, Indonesia \\ sulistiya@uinsby.ac.id
}

\begin{abstract}
Islamic boarding schools (Islamic boarding schools) are Islamic educational institutions that have an important role in improving the quality of human resources. An-Najiyah Islamic Boarding School is the oldest one in Surabaya that has not implemented environmental management. The study was conducted to plan an environmental management system (SML) and fill the gap of SML research in Islamic Education Institutions. The research method is qualitative with environmental aspects studied: clean water, waste, energy, and green area. The SML is reviewed in 2 phases: the operational review phase and identification of activities that might have an impact on the environment and the planning phase of the environmental conservation program. Primary data: results of questionnaires, observation and mapping of existing conditions. Secondary data: area, number of residents, and literature. The results of the first phase show that clean water sources use ground water (37\%) and PDAM (63\%). Domestic wastewater from MCK activities is discharged directly into water bodies without treatment. The solid waste still piled up and scattered with the collection of solid waste transported to the transfer station in Ponpes. There are no energy conservation activities and alternative energy use. Greening activities is still very minimal. Planning results in the second phase on aspects of clean water: installation of automatic tap water, replacement of bathtub with shower, utilization of ex-wudlu, rainwater harvesting, biopori, and infiltration wells. Liquid waste aspects: processing with Anaerobic Baffled Reactor, reuse the results of processing, redesigning biogas septic tanks. Solid waste management using composting and waste banks. Energy aspects: with LED lights and solar panels. Green area: green open space and vertical garden.
\end{abstract}

Keywords: environmental management system, Islamic boarding school, clean water, waste, energy, greening.

\begin{abstract}
Abstrak
Pondok pesantren (Ponpes) merupakan institusi pendidikan islam yang berperan penting meningkatkan kualitas sumber daya manusia. Ponpes An-Najiyah merupakan salah satu pondok tertua di Surabaya yang belum menerapkan manajemen lingkungan. Penelitian dilakukan untuk merencanakan sistem manajemen lingkungan (SML) dan mengisi gap penelitian mengenai SML di Institusi Pendidikan Islam. Metode penelitian merupakan kualitatif dengan aspek lingkungan yang dikaji: air bersih, limbah, energi, dan penghijauan. SML dikaji pada 2 fase: fase kajian operasional dan identifikasi kegiatan yang berdampak pada lingkungan dan fase perencanaan program pelestarian lingkungan. Data primer: hasil kuisioner, observasi dan mapping kondisi eksisting. Data sekunder: jumlah penghuni, serta literatur. Hasil fase pertama menunjukkan, sumber air bersih menggunakan air tanah (37\%) dan PDAM (63\%). Air limbah domestik dari kegiatan MCK dibuang langsung ke badan air tanpa pengolahan. Sampah menumpuk dan tercecer dengan pengumpulan sampah diangkut ke TPS Ponpes. Belum terdapat kegiatan konservasi energi dan penggunaan energi alternatif. Ruang terbuka hijau masih sangat minim. Hasil perencanaan pada fase kedua pada aspek air bersih: pemasangan keran wudlu otomatis, penggantian bak mandi dengan shower, pemanfaatan bekas wudlu, rainwater harvesting, biopori, dan sumur resapan. Aspek limbah cair: pengolahan dengan Anaerobik Baffled Reactor, reuse hasil pengolahan, redesain biogas septic tank. Pengelolaan sampah menggunakan komposting dan bank sampah. Aspek energi: dengan lampu LED dan panel surya. Aspek penghijauan: RTH dan vertical garden.

Kata kunci: sistem manajemen lingkungan, pondok pesantren, air bersih, limbah, energi, penghijauan
\end{abstract}




\section{PENDAHULUAN}

Pondok pesantren (Ponpes) merupakan salah satu institusi pendidikan islam yang memiliki peranan penting dalam menyiapkan generasi islam yang menjaga sebagian imannya dengan menjaga kebersihan. Selain itu, Ponpes memiliki berbagai peran penting dalam meningkatkan kualitas sumber daya manusia (Al Husna, 2017). Jumlah pondok pesantren di Indonesia adalah 14.793 yang terdiri dari $21,5 \%$ ponpes tradisional, $31 \%$ ponpes modern dan $47 \%$ ponpes terpadu atau kombinasi (Depkes RI, 2007). Menurut analisis data statistik Islam (2012), Lembaga-lembaga keagamaan termasuk pesantren banyak dilibatkan untuk melakukan pendekatan pada pendidikan lingkungan (Mangunjaya, 2014).

Salah satu program dari Kementerian Lingkungan Hidup untuk mendorong tumbuhnya aksi nyata dalam mengatasi permasalahan lingkungan melalui jalur agama adalah ekopesantren (KepmenLH, 2009) Perwujudan ekopesantren dapat terlaksana dengan penerapan Sistem Manajemen Lingkungan (SML) yang disesuaikan dengan pondok pesantren.

Sistem Manajemen Lingkungan (SML) awalnya dikembangkan untuk menentukan dan melaksanakan kebijakan lingkungan di industri. Banyak penelitian mengenai implementasi SML di industri, akan tetapi untuk performa institusi pendidikan yang mengimplementasikan SML masih jarang ada (Hens, et.al., 2010). Tidak ada definisi yang pasti untuk sistem manajemen lingkungan. Akan tetapi, merujuk ke ISO 14001, SML dapat didefinisikan sebuah organisasi struktur, tanggung jawab, praktik, prosedur, proses dan sumber daya untuk mengembangkan, mengimplementasikan, mencapai, mengkaji, dan menjaga kebijakan lingkungan (Cascio, 1996).

Sebuah SML di institusi pendidikan adalah satu set yang sistematis dan koheren dalam langkah-langkah dan ketentuan yang dimaksudkan untuk: menghitung, mencegah dan, jika mungkin, membatasi jumlah polusi yang dihasilkan (Van Volsem et al., 1997). Isu tentang manajemen lingkungan kini menjadi kajian yang sangat intens terkait semakin tingginya kasus pencemaran dan kerusakan lingkungan (Sugianti, 2015).

Aspek Lingkungan yang dikaji dalam penelitian SML ini meliputi sumber dan penggunaan air bersih, penggunaan energi, penanganan limbah (padat/sampah dan cair), serta penghijauan di daerah pondok pesantren. Aspek sampah merupakan salah satu aspek lingkungan yang paling diminati untuk dikerjakan (Hens, et.al., 2010). Pada penelitian lain di institusi pendidikan yang lebih tinggi, pengelolaan limbah menjadi isu utama bagi sektor pendidikan yang lebih tinggi secara global (Zhang et al., 2011).

Ponpes An-Najiyah Surabaya merupakan salah satu pondok pesantren tertua di Surabaya yang didirikan pada Tahun 1613 di Sidosermo, Kecamatan Wonocolo, Surabaya. Pondok pesantren An-Najiyah saat ini telah dilengkapi pendidikan formal TK sampai SMU, Madrasah Diniyah Putra dan Putri. Saat ini, selain siswa sekolah, juga terdapat santriwati yang mukim sejumlah 74 santri dan 22 santri pengurus. Kondisi bangunan yang cukup tua, dan belum terdapat manajemen lingkungan.

Kondisi eksisting di Ponpes An-Najiyah menjadi salah satu dasar penelitian perencanaan SML ini. Hasil penelitian dapat diimplementasikan untuk peningkatan kualitas lingkungan, kesehatan penghuni, serta masyarakat sekitar. Selain itu, penelitian ini dilakukan untuk mengisi gap penelitian mengenai SML di Institusi Pendidikan Islam (Ponpes) yang masih belum banyak dikaji/diteliti.

\section{METODE PENELITIAN}

Metode penelitian menggunakan penelitian deskriptif kualitatif dengan komponen yang dikaji meliputi ketersediaan dan sumber air bersih, pengelolaan air limbah dan limbah padat/sampah, penggunaan energi, dan penghijauan. Pelaksanaannya dengan 
mengumpulkan data primer berupa hasil kuisioner dan wawancara, observasi lapangan dan mapping kondisi eksisting dengan google earth dan observasi dengan menggunakan GPS. Sedangkan data sekunder berupa jumlah penghuni, serta kajian pustaka dari beberapa literatur.

Kuisioner dan wawancara dihitung dengan rumus Slovin dengan tingkat eror sebesar $10 \%$. Jumlah santri putri 65 dan 20 pengurus. Sedangkan untuk santri putra 9 dengan 2 pengurus. Jumlah seluruh responden dimasukkan ke dalam rumus Slovin. Jumlah responden yang didapatkan 35 responden, dengan komposisi 7 pengurus dan 28 santri. Pengambilan data primer dan sekunder dilakukan mulai bulan Agustus-September 2018

Pembahasan meliputi perencanaan sistem manajemen lingkungan pada 2 fase, yakni: fase pertama: mengkaji operasional dan mengidentifikasi kegiatan yang mungkin berdampak pada lingkungan, dan fase kedua: perencanaan pada aspek membuat program pelestarian lingkungan.

\section{HASIL DAN PERENCANAAN SISTEM MANAJEMEN LINGKUNGAN}

Analisis hasil penelitian merupakan analisis dari hasil pengumpulan data primer dan sekunder. Kondisi umum lingkungan di Ponpes An-Najiyah merupakan salah satu dasar pertimbangan untuk perencanaan sistem manajemen lingkungan pada keempat aspek. Denah Ponpes An-Najiyah disajikan pada Gambar 1.

\section{Kondisi Lingkungan Eksisting pada Aspek Penyediaan Air Bersih}

Sumber air bersih yang digunakan di Ponpes adalah sumber air tanah dalam/sumur dan air PDAM (Perusahaan Daerah Air Minum) Kota Surabaya. Air bersih yang banyak digunakan bersumber dari PDAM yakni sebesar 63\% dan 37\% dari sumber air tanah. Kualitas sumber air yang digunakan dapat dikatakan cukup baik, hal ini berdasarkan pernyataan responden yang mengatakan kualitas air sangat baik sebesar $37 \%$, baik $28 \%$, cukup baik 26\%, dan 9\% menyatakan kurang baik.

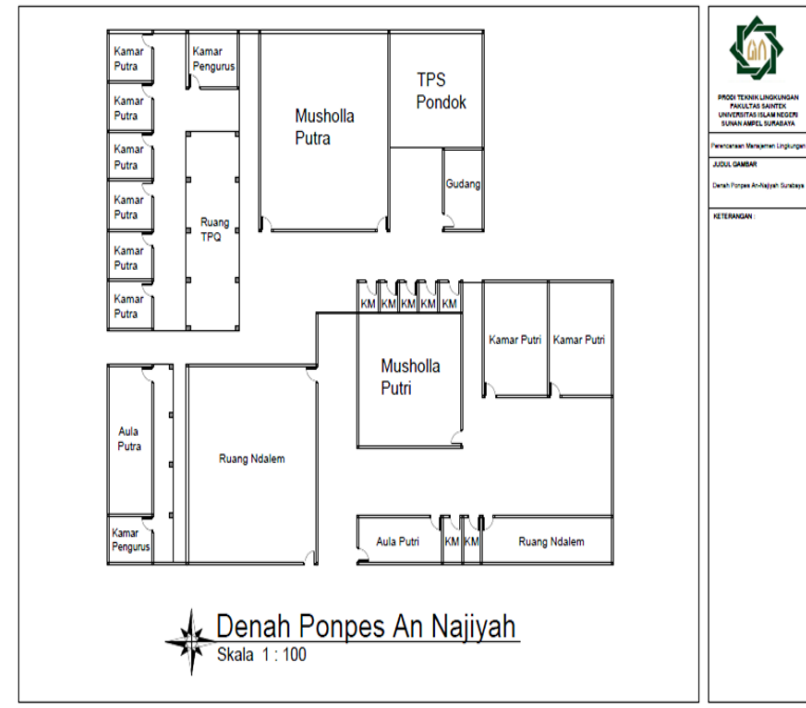

Gambar 1. Denah Pondok Pesantren An-Najiyah

Sumber air digunakan untuk kegiatan mandi, cuci, kakus, dan wudlu. Kebutuhan air bersih juga untuk air minum. Sumber air bersih untuk air minum yang digunakan di ponpes ini $80 \%$ menggunakan air isi ulang, 5\% air minum dalam kemasan, dan 2 $\%$ masih menggunakan air sumur yang direbus.

\section{Kondisi Lingkungan Eksisting pada Aspek Penyaluran Air Limbah}

Saluran limbah cair mencakup ada tidaknya sistem drainase, kondisi saluran drainase dan saluran menuju septick tank. Saluran drainase yang dibuat menggunakan pasangan bata yang diplester. Kondisi saluran drainase terbuka dengan buangan yang cukup pekat dan bau. Hal tersebut disebabkan belum adanya pengolahan limbah domestik di dalam area ponpes dan buangan detergent yang tidak ramah lingkungan, sabun, dll. Terdapat pula sebuah septic tank yang menjadi pusat pengumpulan black water (limbah tinja) di ponpes.

Pada penyaluran air buangan, air limbah yang dihasilkan langsung dibuang ke badan air tanpa adanya pengolahan dikarenakan tidak adanya instalasi/unit pengolahan air limbah. Hal ini juga dikuatkan dari hasil kuisioner yang 
menyebutkan bahwa air langsung dibuang ke selokan sebanyak 91\%.

\section{Kondisi Lingkungan Eksisting pada Aspek Limbah Padat (Sampah)}

Aspek persampahan/limbah padat di Ponpes masih belum dikelola. Beberapa indikatornya dilihat dari proses pewadahan yang dilakukan dan pembuangan akhir di dalam lingkungan pondok. Pewadahan sampah masih sangat sederhana dan jumlah wadah sampah yang masih kurang karena masih banyak sampah yang menumpuk dan tercecer.

Lokasi pewadahan sampah juga masih belum dipertimbangkan, mengingat tidak semua lokasi penghasil sampah memiliki wadah sampah. Wadah sampah eksisting terbuat dari plastik dan kayu.

Sampah dari setiap kamar dikumpulkan ke lahan TPS pondok oleh santri yang sedang piket sampah. Dari proses pengumpulan dari tiap asrama pondok putra dan pondok putri, sampah terkumpul menjadi satu di lahan TPS. Skema angkut-buang masih diterapkan pada proses pengumpulan. Belum ada upaya reduksi sampah berupa pemilahan maupun pengolahan. Hal ini juga didukung dari kuisioner yang menyebutkan tidak adanya kegiatan reduksi sampah dengan komposting.

\section{Kondisi Lingkungan Eksisting pada Aspek Energi}

Aspek energi yang diobservasi meliputi ada tidaknya pemanfaatan energi alternatif, penggunaan lampu hemat energi (LED), dan bentuk-bentuk kegiatan yang bertujuan untuk hemat energi. Di dalam lingkungan Ponpes hampir semua ruangan masih menggunakan lampu neon. Penggunaan lampu LED masih belum banyak digunakan.

Kegiatan pemanfaatan energi dilakukan pada proses pencucian baju secara manual, tidak menggunakan mesin cuci, dan proses pengeringan tidak menggunakan mesin pengering (memanfaatkan energi/panas dari sinar matahari). Akan tetapi, 97\% responden menyatakan masih belum melakukan kegiatan penggunaan sumber energi alternatif seperti surya panel, kincir angin, biogas, dan lain-lain. Ruang-ruang kamar di dalam pondok memiliki ventilasi/jendela yang cukup kecil, sehingga masih membutuhkan lampu penerangan pada siang hari. Beberapa ruangan yang mendapatkan sinar matahari yang cukup, dan dapat menghemat penggunaan lampu pada siang hari, diantaranya pada ruangan yg berada diantara ruang musholla putri, tempat kajian/mengaji, dan beberapa ruang santri putri yang memiliki ventilasi cukup baik.

\section{Kondisi Lingkungan Eksisting pada Aspek Penghijauan}

Pada aspek penghijauan di dalam Ponpes ditinjau dari keberadaan taman atau ruang terbuka hijau, pepohonan, dan tanaman baik di dalam dan depan ruang, dan di depan bangunan di wilayah pondok pesantren.

Lingkungan ponpes masih minim taman, kebun dan ruang terbuka hijau. Hal ini juga dinyatakan oleh $83 \%$ responden yang menyatakan tidak adanya taman, 89\% menyatakan tidak adanya kebun, dan $63 \%$ menyatakan tidak terdapatnya pepohonan di dalam lingkungan pondok. Pernyataan tersebut didukung dari hasil observasi lapangan, dimana jumlah pepohonan dan tanaman hias/kebun masih sangat minim di dalam lingkungan pondok.

\section{Perencanaan Sistem Manajemen Lingkungan \\ Perencanaan sistem manajemen} lingkungan yang direncanakan di Ponpes An-Najiyah dilakukan pada dua fase, yakni: Fase Pertama: kajian operasional dan identifikasi kegiatan yang mungkin berdampak pada lingkungan pada aspek berikut:

1. Air Bersih: kegiatan operasional yang dilakukan berkaitan dengan air bersih adalah penyediaan akses dari sumur dan PDAM yang disalurkan melalui perpipaan menuju ke bak penampung air di fasilitas kamar mandi dan tempat 
wudlu. Belum adanya sistem atau kontrol yang mengatur tentang penggunaan air di dalam pondok pesantren. Penggunaan air tanah juga tanpa adanya upaya konservasi air tanah dengan sumur resapan, lubang biopori, maupun penghijauan di sekitar area pondok, sehingga sebaiknya penggunaan air tanah dikurangi atau ditutup dan menggunakan $100 \%$ dari sumber air PDAM. Pada aspek air bersih, juga masih belum ada kegiatan pemanfaatan air hujan sebagai bentuk usaha mencari alternatif sumber air bersih lain.

2. Limbah: kegiatan yang berkaitan dengan limbah terbagi menjadi 2, dari kegiatan yang berkaitan dengan limbah cair dan padat. Pada limbah cair, sumber penghasil limbah adalah dari kegiatan mandi, cuci, kakus, dan wudlu yang dilakukan di dalam wilayah pondok pesantren. Bahan pencemar yang paling sering ditemui dalam limbah domestik berasal penggunaan detergen, sabun mandi, shampo, dan bahan-bahan kimia lain yang berkaitan dengan aktivitas domestik lain dalam lingkungan pondok. Air limbah yang dihasilkan langsung dialirkan ke saluran drainase dan langsung menuju badan air. Penyaluran air limbah domestik ini tanpa melalui pengolahan. Sedangkan limbah tinja,disalurkan ke dalam septic tank.

Sumber-sumber limbah padat/sampah berasal dari setiap ruang yang ada di dalam Ponpes, seperti ruang kamar asrama putri, ruang kamar asrama putra, musholla, dapur, kamar mandi dan tempat mencuci baju, dll. Sampah yang dihasilkan dibuang ke beberapa wadah sampah yang tersedia di pondok pesantren. Dari beberapa wadah tersebut, diangkut menuju TPS Ponpes. Tidak ada kegiatan pemilahan dan pengolahan baik dari mulai sumber sampah maupun di TPS. Sampah di TPS juga terkadang masih dibakar secara terbuka yang berpotensi menyebabkan pencemaran udara dari proses pembakarannya.
3. Energi: kegiatan yang berkaitan dengan penggunaan dan pemanfaatan energi diantaranya adalah penggunaan lampu di dalam ruangan, pompa listrik untuk menyalurkan air bersih, penggunaan alat-alat elektronik seperti setrika, charger telfon seluler, kipas angin,dll. Pada siang hari, di beberapa ruangan masih belum menerapkan hemat energi karena masih menggunakan lampu disebabkan minimnya ventilasi dalam ruangan. Tidak ada kegiatan pemanfaatan energi alternatif, seperti surya panel, dkk.

4. Penghijauan: Kawasan Ponpes AnNajiyah masih termasuk minim penghijauan. Tidak terdapat program penghijauan, termasuk di depan kamar santri dan di beberapa ruang terbuka yang seharusnya masih bisa dimanfaatkan untuk ruang terbuka hijau.

Fase Kedua: perencanaan pada aspek membuat program pelestarian lingkungan di dalam pondok pesantren An-Najiyah yang meliputi aspek-aspek berikut:

\section{Air Bersih}

Kegiatan dan program yang dapat dilakukan di dalam Ponpes berkaitan dengan konservasi air bersih dan penyediannya dapat dilakukan dengan: (1) Pemasangan pelampung air menggunakan kontak elektrik pada tangki atau toren air yang berfungsi untuk mengatur level ketinggian air bersih agar tidak meluap. Control utamanya memanfaatkan sistem kerja pelampung, saklar dipasang di posisi paling atas, bila pelampung diangkat oleh air sampai ketinggian yang telah ditentukan dan menyentuh switch maka dengan sendirinya pompa akan mati secara otomatis (Prihantoro dan Husni, 2011). Alat ini akan mencegah kebocoran air bersih akibat luapan dari tangki yang lupa dimatikan pompanya ketika pengisian air. (2) Pemasangan keran wudlu otomatis sebagai bentuk efisiensi air bersih. Keran wudlu hemat air ini, jika diaplikasikan akan dapat 
menghemat penggunaan air bersih dalam berwudlu sebesar 41,8\% (Agustiawan dan Hadi, 2017). (3) Mengganti bak air mandi dengan shower mandi. Penggunaan air dengan shower saat mandi jauh lebih hemat daripada menggunakan bak air mandi dengan gayung, selain itu menggunaan shower untuk mandi dapat diperoleh lebih banyak ion negative yang bermanfaat bagi kulit (Oktaviati, 2015). Menurut Yudo (2018), jumlah rata-rata air bersih yang dibutuhkan untuk sekali mandi dengan shower sebesar 60,27 liter, sedangkan jika mandi menggunakan bak air dengan gayung akan menghabiskan rata-rata 75-100 liter. Maka mandi dengan shower dapat menghemat air bersih hingga 39\%. (4) Menggunakan kloset hemat air. Jika kloset eksisting adalah kloset yang disiram secara manual, maka perlu adanya himbauan menggunakan air seperlunya untuk flushing. Sedangkan untuk jangka panjangnya nanti, jika Ponpes AnNajiyah ingin merehabilitasi atau membangun MCK baru, maka disarankan menggunakan toilet dual flush. Toilet dual flush memiliki dua tombol flushing, tombol kecil mengeluarkan air 3 liter sekali tekan (untuk menyiram air seni), sedangkan tombol besar 6 liter sekali tekan (untuk flushing tinja). (5) Pemanfaatan air bekas wudlu untuk menyiram tanaman. Daur ulang air sangat tepat diaplikasikan pada institusi yang membutuhkan air bersih dalam jumlah besar, terutama ponpes yang hampir semua santri dan pengasuhnya beraktivitas selama 24 jam di dalam pesantren. Suatmoko (2007) telah melakukan penelitian terhadap air bekas wudlu di Masjid Ulil Albab Universitas Islam Indonesia, dimana polutan tertinggi air bekas wudlu adalah Chemical Oxigen Demand (COD) 40 $\mathrm{mg} / \mathrm{liter}$ dan E.coli $4 \mathrm{MPN} / 100 \mathrm{ml}$. Kandungan polutan yang kecil tersebut cukup diolah dengan adsorpsi menggunakan karbon aktif atau menggunakan filter. Adsorpsi menggunakan karbon aktif dapat mengurangi kadar COD hingga 48\% dan mengurangi kandungan bakteri E.coli hingga 67\% (Suatmoko, 2007). (6) Pemenuhan kebutuhan air bersih di dalam pondok pesantren dengan rainwater harvesting sistem. Rainwater harvesting merupakan suatu kegiatan untuk mengumpulkan, menggunakan, dan menyerap air hujan ke dalam tanah (MenLH, 2009). Hasil dari rainwater harvesting juga dapat dimanfaatkan sebagai cadangan air untuk flushing closet. Untuk memanen air hujan perlu dibuat sistem yang terdiri dari talang dan kolam pengumpul (MenLH RI, 2009). Rainwater harvesting sistem harus dilengkapi dengan pipa flushing yang tidak terhubung ke tangki penambung dan langsung ke saluran drainase. Jika air hujan digunakan untuk kebutuhan konsumsi, maka dilengkapi dengan bangunan filter sederhana sebelum masuk ke dalam tangki penampung. (7) Pembuatan sumur resapan untuk konservasi air tanah. Manfaat dari sumur resapan menurut Yudo (2018) adalah: Menambah jumlah air yang masuk ke dalam tanah sehingga menjaga kesetimbangan hidrologi air tanah, mencegah intrusi air laut, mereduksi dimensi jaringan drainase, menurunkan konsentrasi pencemaran air tanah, mempertahankan level muka air tanah, mengurangi limpasan air hujan sehingga mencegah banjir, mencegah terjadinya menurunan tanah. Desain sumur resapan ditentukan berdasarkan kedalaman sumur resapan pada luas atap bangunan Ponpes. Beberapa parameter yang perlu diperhatikan dalam mendesain sumur resapana adalah kedalaman muka air tanah dan nilai permeabilitas tanah (Indramaya dan Purnama, 2013). (8) Pembuatan Lubang Resapan Biopori (LRB) sebagai bentuk konservasi air tanah karena dapat menjadi water reservoir dan mitigasi terhadap genangan di musim hujan. LRB 
merupakan teknologi ramah lingkungan dan tepat guna untuk ketersediaan air tanah dengan memanfaatkan sampah organik biodegradable melalui pembuatan lubang kecil di dalam tanah (Yohana, 2017). LRB yang dibuat dapat berukuran diameter 10-20 $\mathrm{cm}$ dengan kedalaman menyesuaikan level muka air tanah hingga batas maksimal kedalaman $100 \mathrm{~cm}$. Dinding lubang direncanakan terbuat dari pipa PVC agar tanah tidak longsor sehingga menutupi LRB, pipa diberi lubang-lubang kecil (perforated) disepanjang badan pipa agar organisme dan mikroorganisme tanah dapat masuk ke dalam LRB. Pembuatan LRB direncanakan dibuat di seluruh areal kosong di Ponpes AnNajiyah degan jarak antar lubang berkisar 50-100 cm. (9) Sosialisasi hemat air yang dilakukan secara masif di dalam lingkungan ponpes, terutama di dekat sumber air bersih (sumur), di tiap pintu kamar mandi, dan lokasi-lokasi yang terdapat sanitair. Sosialisasi dapat dilakukan dengan menempelkan stiker atau poster yang berisi ajakan menghemat penggunaan air.

\section{Limbah}

Kegiatan dan program-program terkait limbah dapat dilakukan dengan beberapa cara, diantaranya:

Limbah Cair : (1) Pembuatan instalasi pengolahan air limbah domestik. Teknologi pengolahan yang cocok diterapkan di lingkungan pesantren yang banyak aktivitas dengan keterbatasan lahan adalah Anaerobic Baffled Reaktor (ABR) dengan kombinasi anaerobic filter (AF). ABR memiliki efisiensi pengolahan yang tinggi, tidak memakan banyak lahan karena dapat dibangun di bawah tanah sehingga lahan di atas ABR dapat dimanfaatan untuk kegiatan lain, serta biaya operasional yang rendah (Rahmanissa dan Slamet, 2017). (2) Penggunaan kembali air limbah untuk menyiram tanaman. (3) Sosialiasi pengurangan konsumsi/penggunaan bahan-bahan kimia (detergen, sabun, pembersih, dll). (4) Penggunaan bahan pembersih atau bahan kimia lain yang ramah lingkungan untuk dipakai di dalam pondok pesantren. Merancang ulang (redesain) septic tank untuk memanfaatkan limbah tinja (black water) sebagai biogas. (6) Sosialiasi pengurangan konsumsi/penggunaan bahan-bahan kimia (detergen, sabun, pembersih, dll). Limbah Padat/ Sampah: (1) Reduksi sampah di sumber sampah dengan melakukan pemilahan sampah organik (sisa makanan, sampah kebun,dll) untuk komposting, sampah yang masih bisa didaur ulang seperti botol plastik, kaleng, kertas, dan pemilahan sampah yang sudah tidak dapat dimanfaatkan/didaur ulang kembali. Komposting dapat dilakukan dengan keranjang takakura agar lebih tertutup, tertata rapi, baik secara estetika, dan tidak menimbulkan bau, karena beberapa sumber sampah merupakan kamar para santri. Komposting dapat juga dilakukan dengan komposter komunal, yang diletakkan di setiap beberapa ruangan atau 2-3 gedung/bangunan dalam Ponpes. Komposter direncanakan terbuat dari bahan tong atau drum platik bekas yang dilengkapi dengan dua paralon berlubang kecil-kecil (perforated) dengan panjang berbeda membentuk huruf $\mathrm{T}$ dan dilengkapi sebuah keran di bagian bawah tong. Lubang pada paralon berfungsi sebagai tempat sirkulasi udara agar oksigen dapat masuk ke reactor, dan gas hasil penguraian sampah dapat keluar. Keran yang dipasang dibawah befungsi untuk mengeluarkan air lindi. Kompos yang dihasilkan dapat dijual atau dimanfaatkan sendiri untuk lahan hijau Ponpes. (2) Bank sampah yang berfungsi untuk mengumpulkan sampah dari penghuni pondok dan juga menerima sampah recyclable dari masyarakat sekitar Ponpes. (4) Pada TPS diterapkan unit pemilahan 
sederhana, dimana sampah organik langsung masuk komposter komunal, sampah recycable yang masih bisa didaur ulang masuk bank sampah, sehingga sampah yang tersisa di dalam TPS hanya sampah residu yang akan diangkut ke TPA. (5) Sosialisasi kebijakan lingkungan dan himbauan untuk melakukan kegiatan reduksi sampah di pondok pesantren dengan $5 \mathrm{R}$, reduce, reuse, recycle, revalue, dan recovery (memulihkan kembali sampah dengan memanfaatkan sampah, misalnya sebagai bahan energi alternatif).

\section{Energi}

Kegiatan dan program yang dapat dilakukan berkaitan dengan energi, dapat dilakukan dengan beberapa cara, diantaranya: (1) Memperlebar atau menambah ventilasi di tiap ruang, agar pencahayaan pada siang hari cukup menggunakan sinar matahari, tanpa menyalakan lampu. (2) Penggantian lampu neon dengan lampu LED (Light Emitting Diode) yang lebih hemat energi (3) Pemanfaatan energi sinar matahari untuk sumber cadangan energi listrik alternatif dengan pemasangan panel surya (solar cell), baik di atap bangunan pondok, maupun diatas tiap lampu penerangan di luar bangunan. (4) Kebijakan lingkungan dan sosialisasi hemat energi, misalkan peraturan penggunaan lampu hanya pada malam hari/gelap, dan selalu mematikan listrik dan atau lampu setelah digunakan.

\section{Penghijauan}

Program dan kegiatan berkaitan dengan penghijaun dapat dilakukan dengan beberapa cara, diantaranya: (1) Penyediaan ruang terbuka/taman untuk ditanami pohon tingkat tiang yang mampu mereduksi gas pencemar (2) Karena keterbatasan lahan, penanaman pohon dapat dilakukan dengan media tanam dalam pot/tong bekas dengan peletakan untuk beberapa area tertutup/dalam ruang, seperti di depan ruang-ruang kamar, musholla, dll. (3) Penerapan vertical planting baik dengan tanaman yang dapat merambat atau menempel pada dinding, pipa atau penyangga, atau dengan hidroponik. Lebih baik lagi jika media tempel tanaman menggunakan sampah yang di-reuse. Sistem tanaman rambat dinding ini memiliki kelebihan melindungi dinding dari paparan langsung sinar matahari sekaligus menurunkan temperature ruangan sehingga lebih sejuk (Tasidin, 2017). (4) Aplikasi green roof (atap hijau) yang merupakan pemanfaatan atap untuk taman yang berfungsi menurunkan suhu bagian atap dan ruangan di bawahnya. (5) Memilih tanaman harus memperhatikan faktor fungsi, kegunaan/manfaat, perakaran, lokasi, dan pemeliharaan. Temperature di Ponpes An-Najiyah terbilang cukup tinggi, oleh karena itu tanaman yang cocok untuk penghijauan adalah tanaman yang bisa menjaga suhu tetap sejuk, seperti: palem bambu (Chamaedorea seifrizii), sri rejeki (Aglaonema modestum), sirih gading (Eppremnum aureum), Sanseviera (Sanseviera trifasciata), lidah buaya (Aloe vera), dan lain-lain (6) Kebijakan lingkungan yang mengatur tentang 1 jiwa 1 pohon atau tanaman.

\section{KESIMPULAN}

Kesimpulan yang dapat diambil dari penelitian ini adalah:

1. Kajian operasional dan identifikasi kegiatan yang mungkin berdampak pada lingkungan pada aspek berikut: (fase pertama) menunjukkan:

- Sumber air bersih yang bersumber dari PDAM yakni sebesar 63\% dan $37 \%$ dari sumber air tanah. Air bersih yang digunakan disalurkan melalui perpipaan menuju alat2 sanitair di ponpes dan untukpenggunaan kegiatan domestik. 
- Pada penyaluran air buangan, air limbah yang dihasilkan berasal dari kegiatan MCK yang langsung dibuang ke badan air tanpa adanya pengolahan. Untuk limbah tinja langsung masuk ke septic tank.

- Sampah yang dihasilkan berasal dari asrama santri putra dan putri, asrama, kamar mandi, dll. Kegiatan angkut buang di TPS Ponpes AnNajiyah tanpa kegiatan pengolahan dan reduksi sampah di sumber.

- Pada aspek energi, dari penggunaan alat2 elektronik di Ponpes, dan penggunaan lampu neon. Selain itu, tidak terdapat kegiatan pemanfaatan energi alternatif di dalam lingkungan Ponpes.

- Lingkungan Ponpes masih minim taman, kebun dan ruang terbuka hijau.

2. Hasil perencanaan Sistem Manajemen Lingkungan (fase kedua) yang sesuai dan paling mungkin untuk diaplikasikan di Ponpes An-Najiyah adalah sebagai berikut:

- Aspek air bersih, diantaranya dengan modifikasi sanitair yang digunakan, seperti pemasangan pelampung air dengan kontak elektrik pada tangki, dan pemasangan keran wudlu otomatis. Untuk konservasi air tanah yang digunakan, dengan sumur resapan, biopori, dan rainwater harvesting sebagai alternatif sumber air bersih.

- Aspek limbah, untuk limbah cair dengan perencanaan instalasi pengolahan air limbah domestik dengan Anaerobik Baffled Reactor (ABR), reuse hasil pengolahan, redesain biogas septic tank. Limbah padat/sampah dengan reduksi dengan prinsip 3R menggunakan komposter dan pembuatan bank sampah di Ponpes.

- Aspek energi, dengan penggantian lampu neon dengan lampu LED (Light Emitting Diode), pemanfaatan energi sinar matahari dengan panel surya (solar cell).
- Aspek penghijauan, dengan penyediaan RTH untuk ditanami pohon tingkat tiang yang mampu mereduksi gas pencemar, green roof, dan vertical planting.

\section{DAFTAR PUSTAKA}

Agustiawan, dan Abdul Hadi. 2017. Efisiensi Rancang Bangun Keran Wudhu Otomatis Hemat Air. Seminar Nasional Teknologi Informasi, Komunikasi dan Industri 9. Fakultas Sains dan Teknologi. UIN Sultan Syarif Kasim Riau. Pekanbaru, 18-19 Mei 2017.

Al Husna, Ika Maulida, Atmaja,Hamdan Tri,Bain. 2017. Peranan Pondok Pesantren Al-Fatah Parakancanggah dalam Perkembangan Pendidikan dari Tradisional Menuju Modern di Kabupaten Banjarnegara Tahun 1941-1992. Journal of Indonesian History 6 (1).

Cascio J, editor. 1996. The ISO 14000 handbook. Milwaukee: ASQ Quality Press.

Hens L., Wiedemann T., Raath S., Stone R., Renders P., Craenhals E. 2010. "Performance of Newly Implemented Environmental Management Systems in Primary Schools in South Africa". Journal of Environmental Management 91; 906-917.

Indramaya, E.A. dan Purnama, I.L. 2013. Rancangan Sumur Resapan Air Hujan sebagai Salah Satu Usaha Konservasi Air Tanah di Perumahan Dayu Baru Kabupaten Sleman Daerah Istimewah Yogyakarta. Skripsi. Program Studi Geografi dan Ilmu Lingungan, Universitas Gadjah Mada. Yogyakarta

Kementerian Lingkungan Hidup Republik Indonesia. 2009. Peraturan Menteri Negara Lingkungan Hidup No. 12 Tahun 2009 Tentang Pemanfaatan Air Hujan. Jakarta

Mangunjaya,F.M, 2014. Bagaimana Merancang Pesantren Ramah 
Lingkungan? Yayasan Pustaka Obor Indonesia. Jakarta

Prihantoro, T.B. dan Husni, R.C.W. 2011. Alat Pendeteksi Tinggi Permukaan Air secara Otomatis pada Bak Penampung Air Menggunakan Sensor Ultrasonik Berbasis Mikrokontroler. Skripsi. Program Studi Teknik Komputer AMIK MDP. Palembang

Rahmanissa, A. dan Slamet, A. 2017. Perencanaan Sistem Penyaluran dan Pengolahan Air Limbah Domestik Kecamatan Semarang Barat Kota Semarang. Jurnal Teknik ITS Vol. 6 No.2. Hal: D147-D151

Oktaviati, R. 2015. Politeknik Negeri Sriwijaya. Palembang

Suatmoko, D. 2007. Daur Ulang Air Bekas Wudlu (Studi Kasus Masjid Ulil Albab Universitas Islam Indonesia). Tugas Akhir, Universitas Islam Indonesia. Jogjakarta

Sugianti, Y. 2015. Sistem Manajemen Lingkungan. Program Studi Teknik Lingkungan, Fakultas Teknik Sipil dan Lingkungan, Institut Teknologi Bandung. Bandung

Tasidin, M.S. 2017. Pondok Pesantren Modern dengan Konsep Green Building di Kabupaten Gowa. Tugas Sarjana Arsitektur. Jurusan Arsitektur, Univertitas Hasanuddin. Makassar

Van Volsem, S., Vens, V. (Eds.), 1997. Schools, Universities and the Environment. International Seminar on Environmental Care and EMS in Schools and Universities. VUB, Department of Human Ecology, Brussels.

Yohana, C., Griandini, D., dan Muzambeq, s. 2017. Penerapan Pembuatan Teknik Lubang Biopori Resapan sebagai Upaya Pengendalian Banjir. Jurnal Pemberdayaan Masyarakat Madani (JPMM) Vol. 1 No. 2. Hal: 296-308

Yudo, S. 2018. Upaya Penghematan Air Bersih di Gedung Perkantoran Studi Kasus: Penghematan Air di Gedung
Kantor BPPT. Jurnal Teknologi Lingkungan Vol. 19, No.1. Hal: 97105

Zhang N., Williams I.D., Kemp S., Smith N.F. 2011. "Greening academia: Developing sustainable waste management at Higher Education Institutions". Waste Management 31;1606-1616. 